Special Issue of the 7th International Advances in Applied Physics and Materials Science (APMAS 2017)

\title{
Investigation Effect of Different Feldspar Ratio on the Mechanical Properties of Porcelain Ceramic Foam Prepared by Polymeric Sponge Method
}

\author{
M. Mohammed* and S. Shahatha \\ Department of Applied Sciences, University of Technology, Baghdad, Iraq
}

\begin{abstract}
This paper studies the effect of different feldspar ratios on the mechanical properties of porcelain ceramic foam. The study is based on polymeric foam templates impregnated in ceramic slurry with solid loading ranging from 25 to $35 \mathrm{wt} \%$ under vacuum of $10^{-1}$ Torr and then sintered to $1250^{\circ} \mathrm{C}$. Effect of different feldspar solid loadings quantities was evaluated based on porosity, density and mechanical properties (compressive and flexural strengths) of the ceramic foam
\end{abstract}

DOI: 10.12693/APhysPolA.134.252

PACS/topics: vacuum, microwave drying, polymeric sponge method, porcelain ceramic foam

\section{Introduction}

Ceramic foam is a porous ceramic material (see Fig. 1) with porosity ranging between $70 \%$ and $90 \%$ [1]. It has become increasingly important in industry recently due to their numerous applications [2], like catalyst carriers, filters for molten metal, water, waste water, hot exhaust gases, insulation, biomedical devices, catalytic converter, membrane absorbents, due to their high surface area, high permeability, good thermal properties, high strength, resistance to chemical attacks [3, 4]. Polymeric sponge method is in fact considered as the first method deliberately used for the production of the macroporous ceramics [5]. The process involves coating of open-cell polymeric sponge with ceramic slurry sponge through sintering process, which yields a replica of the ceramic foams that tend to possess a lower mechanical strength, and a higher permeability. The aim of this article is to find out the effect of different feldspar ratios on the mechanical properties of the ceramic foam [6].

\section{Experimental}

Polymeric sponges used each were cut into a dimension of $70 \mathrm{~mm} \times 30 \mathrm{~mm}$ with the different thicknesses for compression and flexural tests. Feldspar, silica and kaolin in the ratios of 25,25 and $50 \mathrm{wt} \%$ were mixed to produce porcelain powder. The ceramic slurry was prepared in the range of 25 to $35 \mathrm{wt} \%$ of feldspar ratio in constant of kaolin. The mixture was stirred in mechanical stirrer for $15 \mathrm{~min}$. Prior to the dipping process, the viscosity of the ceramic slurry was measured using viscometer (model RTV) at spindle speed of $100 \mathrm{rpm}$. The foam was squeezed manually and then put in a bell jar and evacuated to $10^{-1}$ Torr to remove the trapped air and make sure that the sponge saturated with the ceramic

\footnotetext{
*corresponding author; e-mail: dr_mothaffer@yahoo.com
}

slurry. Any excess slurry was removed by squeezing the template through a roller. The loaded templates were dried in a microwave oven for 10 to 12 min according to the thickness. The sample was sintered at $1250{ }^{\circ} \mathrm{C}$ with heating rate $5{ }^{\circ} \mathrm{C} / \mathrm{min}$, one hour of soaking time. The porosity was determined using the Archimedes method and the particle size was measured by laser particle size analyzer. Mechanical properties of the ceramic foams at various thicknesses were determined by compression test ASTM C77-88 (1999) using Instron machine model 1195 at crosshead speed of $1 \mathrm{~mm} / \mathrm{min}$ and flexural test (ASTM C1161-94) (three point bending) using Instron machine model 1195 at crosshead speed of $0.5 \mathrm{~mm} / \mathrm{min}$. The morphological study was performed using scanning electron microscope.

\section{Results and discussion}

\subsection{Morphology of polymeric foam template}

The morphology of polymeric foam is directly related to the microstructure of the polymer foam templates. It has been observed that the quality of ceramic foam is strongly influenced by the density of the slurry, and this reflects the degree of porosity (Fig. 2). Reducing the porosity will consequently increase the density of ceramic foam from 1.335 to $1.562 \mathrm{~g} / \mathrm{cm}^{3}$; it was found that the slurry density greater than $1.562 \mathrm{~g} / \mathrm{cm}^{3}$ is undesirable because this promotes the formation of cavity inside the ceramic foam which could be attributed to a poor slurry flow and coating. Another factor which could also affect the density and porosity is the microstructure of the polymeric sponge foam which broadly consists of open and closed-cell structures. Uncoated polymeric foam will become a cavity due to the burn-off process which later takes part in low density and weak spot in the foam.

\subsection{Microstructural analysis}

Figure 3a shows the scanning electron microscopy (SEM) micrographs of ceramic foam. It is obvious that 


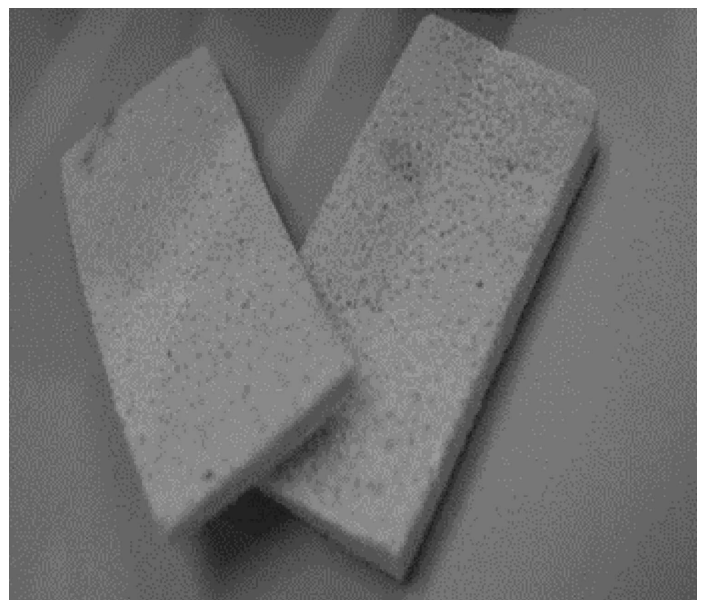

Fig. 1. Optical micrograph of the polymeric foam.
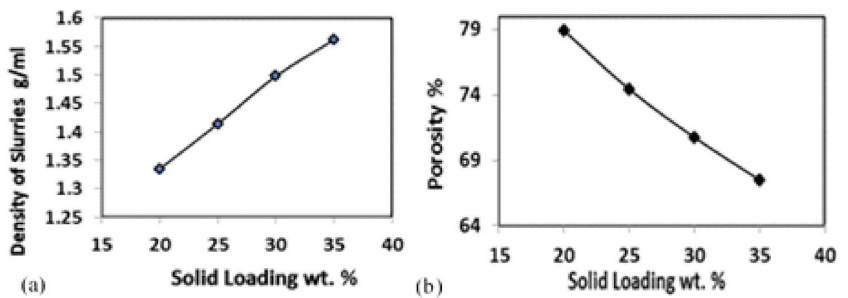

Fig. 2. Density of slurries and porosity of the foam at different feldspar ratios.

the amount of porous structure increases with increasing density of slurry, it was also clear that the cell wall thickness of the ceramics foam microstructure has increased with increasing solid loading. The cell structure of the foam consists of open cell and close cell with a majority of dense portion. Figure $3 \mathrm{~b}$ shows the elemental analysis of the fired ceramic foam using energy dispersive X-ray (EDX) technique. Elements like K, Zn, Si, Al, C and O element were noticed in the ceramic foam presenting the organic and inorganic elements existing in the foam.

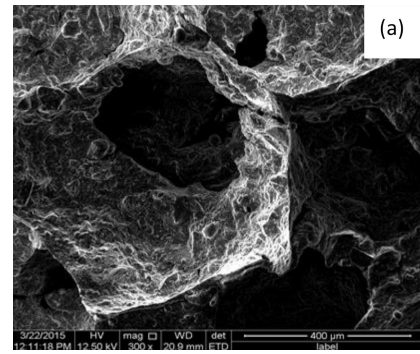

Spectrnn: Acquisition 271

El AN Series un. C nom. C Atom. C Error (1 Signa) [wt.8] [wt.8] [at. [wt.

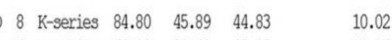
C 6 K-series $64.12 \quad 34.69 \quad 45.15 \quad 10.06$

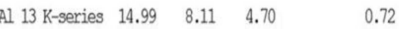
$\begin{array}{lllll}\text { Si } 14 \text { K-series } & 14.89 & 8.06 & 4.48 & 0.65\end{array}$ an 30 L-series $\quad 5.41 \quad 2.93 \quad 0.70 \quad 0.39$

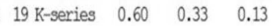

Total: $184.81 \quad 100.00 \quad 100.00$

Fig. 3. (a) SEM image of sintered ceramic foam, and (b) EDX analysis.

\subsection{Crushing strength and flexural strength}

Figure $4 \mathrm{a}$ shows the variation of the compressive strength of the ceramic foam which was calculated ac- cording to ASTM C271-94 as a function of solid loading of the slurry. As can be noticed, compressive strength increases from 10.23 to $16.63 \mathrm{MPa}$ with increasing slurries density from 1.335 to $1.562 \mathrm{~g} / \mathrm{cm}^{3}$. Results show that the compression strength of the foam structure is dependent upon the area within the structure that acts as load-bearing strut. A denser packing of ceramic particles around these areas helps to increase the effective load bearing area and increase the strength. The ceramic foams produced at slurry density $1.498 \mathrm{~g} / \mathrm{cm}^{3}$ have the highest values of compressive strength.

Figure $4 \mathrm{~b}$ shows the variation of the flexural strength of the ceramic foam as a function of slurry density. From this figure it is clearly seen that the flexural strength increases from 6.57 to $14.2 \mathrm{MPa}$ as slurry density increases from 1.335 to $1.498 \mathrm{~g} / \mathrm{cm}^{3}$ and decreases to $8.52 \mathrm{MPa}$ at $1.562 \mathrm{~g} / \mathrm{cm}^{3}$. Similar reason could be applied to the increase in flexural strength the same as compressive strength where a denser packing of ceramic particles help to increase the effective load bearing area and there increasing the strength. The ceramic foam produced at $1.498 \mathrm{~g} / \mathrm{cm}^{3}$ was found to have the highest values of flexural strength.
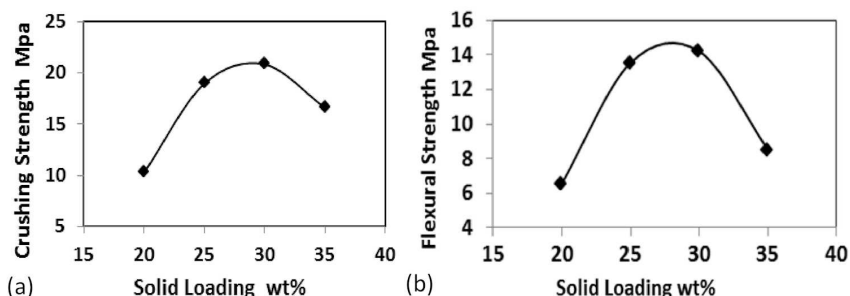

Fig. 4. (a) Crushing strength at different feldspar ratios, and (b) flexural strength at different feldspar ratios.

\section{Conclusion}

Ceramic foams were successfully synthesized using polymeric foam method and known also as replication method. It was observed that the mechanical properties of the ceramic foam are greatly influenced by the preparation under vacuum and microwave drying which enhance the mechanical strength more than 3 times as well as its density thus making the foam denser.

\section{References}

[1] J.-Y. Zhang, Y.-M. Fu, X.-M. Zeng, Trans. Nonferrous Met. Soc. China 16, 453 (2000).

[2] J.K. Efavi, Ceram. Int. 36, 673 (2010).

[3] F.F. Lange, K.T. Miller, Adv. Ceram. Mater. 2, 827 (1987).

[4] L.M. Sheppard, Ceram. Trans. 31, 3 (1992).

[5] K. Schwartzwalder, A.V. Domers, Method of Making Porous Ceramic Articles, US Pat. No. 3090094 (1963).

[6] A. Korjakins, L. Upeniece, D. Bajare, in: 4th Int. Conf. Civil Engineering'13 Proceedings, Part II, Construction and materials, 2013. 